\title{
Exploring Nexus Between Spiritual Intelligence and Leadership Success of BES JA's President
}

\author{
R Tsaniyah ${ }^{1}, \mathrm{~N} \mathrm{Huda}^{2}$ \\ ${ }^{1}$ Jagad 'Alimussirry Islamic Boarding School Surabaya, Indonesia \\ ${ }^{2}$ Sunan Ampel Islamic State University Surabaya, Indonesia \\ Email: tsaniyahrohmatus@gmail.com
}

\begin{abstract}
Leadership is the ability to influence a group towards achieving goals. A leadership certainly has a benchmark of leadership success which will further be referred to as an indicator of leadership success, which is certainly related to the course of the organization during his leadership. The success of leadership is caused by several factors, one of which is spiritual intelligence. The purpose of this study is to describe the spiritual intelligence of President BES JA, the success of President BES JA's leadership, and the relationship between the two. This research is a descriptive type of research with a qualitative approach. The subjects of this study were the three old Presidents of BES JA. The results of this study are that the President of BES JA has a good relationship with Allah SWT and relations with fellow human beings and their leadership at BES JA in each period is considered quite successful in developing work programs, formulation and implementation of the regulations of the cottage, and the way BES JA stewardship wheels. And there is a link between spiritual intelligence and leadership success.
\end{abstract}

Keywords : Spiritual intelligence, leadership success

\section{INTRODUCTION}

Humans created by Allah SWT on this earth have two responsibilities namely the first as' abdun (servant) who must always obey the creator, Allah SWT, by carrying out all His commands and avoiding all His prohibitions according to the word of God SWT in Al-Quran surah Adz-Dzariyat verse 56. While the second is as a khalifah (leader) on this earth, either for himself or for many people according to the word of Allah SWT in Al-Quran surah AlBaqoroh verse 30. Regarding leadership itself, according to Dubin (in Hartono, 2016) is the activity of power holders and decision makers. Meanwhile according to Robbins (in Hartono, 2016) said that "Leadership is ability to influence group a certain to purpose the goal achievement" which means that leadership is the ability to influence a group towards achieving goals. This opinion views all members of a group or organization as a whole, so that leadership is given meaning as the ability to influence all members or groups to be willing to carry out activities / work to achieve organizational goals.

A leadership certainly has a benchmark of leadership success which will further be referred to as an indicator of leadership success, which is certainly related to the course of the organization during his leadership. The success of leadership is caused by several factors, one of which is spiritual intelligence. Hick (in Hartono, 2016) said that "the experience of spirituality for those who experience it themselves is rational but for those who have not experienced it may be considered irrational and far from objectivity." The cause of this condition is because the spiritualist is able to uncover and empower the potential of the divine nature that exists in him from his human 
nature. This kind of spiritualist is because he is radiated by Allah's care, so that he rises to reach a high level of dignity bearing the title of the perfect man or to become the holy guardian of God.

Life in this world for the spiritualist is a fact that cannot be denied. They face it realistically. With closeness to God, a spiritualist will always feel confident and optimistic. His activities will always light up because all that is done is aimed at seeking God's pleasure. Seeing this kind of condition, it cannot be denied that spirituality is really needed by humans who crave success from their life goals. According to Hartono (2016) the title of The Perfect Man / human beings actually reflects the perfect human figure who succeeded in carrying out his duties either as Abdullah or caliph (leader) simultaneously. In the Jagad Islamic Boarding School 'Alimussirry there are several organizations, one of which is the Executive Board of the Islamic Student Jagad' Alimussirry (BES JA), the highest leadership of BES JA is held by BES JA President. Due to research conducted by researchers in the scope of Jagad Islamic Boarding School 'Alimussirry, researchers are interested in conducting research under the title "Implementation of Spiritual Intelligence in the Success of BES JA Leadership" with the aim of describing the spiritual intelligence of President BES JA, describing the success of the leadership of President BES JA, and describing the relationship the spiritual intelligence of President BES JA with the success of his leadership.

\section{METHOD}

The aims of this study are to describe the spiritual intelligence of President BES JA, the success of the leadership of President BES JA, and the relationship between the two. Based on the research objectives, this research is a type of descriptive research with a qualitative approach. This study uses two types of instruments, the main instrument is the researcher himself and the supporting instrument, namely the interview guide. The data of this study were obtained from interviews. The purpose of this interview is to dig deeper information about the spiritual intelligence of President BES JA and the leadership success of President BES JA. Data analysis of the results of the interviews was carried out through three stages namely data reduction, data presentation, and drawing conclusions.

Table 1. Indicators of Spiritual Intelligence

\begin{tabular}{|c|c|}
\hline \multicolumn{2}{|c|}{ Indicators of Spiritual Intelligence } \\
\hline Relationship to & Prayer \\
God & Fasting \\
& Pray \\
\hline Human & Responsible \\
relationship & Honest \\
& Trustful \\
\hline
\end{tabular}

Table 2. Indicators of Leadership Success

\begin{tabular}{|l|}
\hline \multicolumn{2}{|l|}{ Indicators of Leadership Success } \\
\hline 1. \\
Enthusiastic JA students in \\
participating BES's programs. \\
2. Attention of JA students when \\
President of BES JA spoke. \\
3. The influence of the words of President \\
of BES JA on the JA students.
\end{tabular}

\section{RESULT AND DISCUSSION}

In this discussion, it will be divided into 3 main topics, namely spiritual intelligence, leadership at BES JA, and the relationship between spiritual intelligence and the success of BES JA presidential leadership.

\section{- Spiritual Intelligence}

From the indicators of relationship to Allah, the researcher divides this theme into 3 sub-groups, namely prayer, fasting, and pray. From some of the questions raised by researchers regarding prayer, answers to the three research subjects were almost the same. Regarding fardhu prayer, when the three subjects were asked about prayer at the beginning of time and in congregation, they had the same answer 
that they often, but not always, prayed at the beginning of time. The reason why is not always, because sometimes there are jobs that cannot be left behind and if left behind will affect many people. Furthermore, regarding the sunnah prayers that they usually do there are several different ones. The first subject has the status of establishing rawatib prayer (qobliyah and ba'diyah), duha prayer, and repentance prayer. Other sunnah prayers, such as tahajjud, hajat, tasbih, witir, etc., have also been carried out but still cannot be Istiqomah. The second and third subjects have the rawatib prayer (qobliyah and ba'diyah), duha prayer, tahajjud prayer, and hajat prayer. Other sunnah prayers such as repentance prayer, prayer tasbih, witir, eclipse, istisqo 'have also been done but it still depends on time and conditions.

The second sub is fasting. In terms of fasting the third subject of the sunnah has no significant difference. All three subjects have a term in doing fasting Monday-Thursday. Other Sunnah fasts such as fasting tasu'a, ashura, arafah have also been done by them, but for the terminology it still depends on the situation at that time. In addition, the three subjects also took part in the Islamic Boarding School Jagad 'Alimussirry, but with different achievements. Then the third sub is pray. All three subjects had the term of praying after the fardhu prayer. But there are still a little different, the first subject also reads other pray but still cannot istiqomah, whereas for the second and third subjects also read other pray which is read after sunset and dawn and can still be istiqomah until now. Of all the things submitted by the subject to researchers also in accordance with a statement made by one of the students of the Islamic Boarding School Jagad 'Alimussirry that the three subjects do have a good relationship to God, even though it is still not perfect.
In terms of human relationships, there are no significant differences between the three subjects. All three subjects have good trust and responsibility. When researchers ask them if they have previously thought about becoming BES president. All three subjects agreed to answer never. Next, the researchers asked if they never thought what made them willing and confident to become the President of BES. Their answers are not exactly the same, but it leads to the same answer, that is, if it's already from the clerics, then it's the best. Therefore, they continued to carry out the mandate as BES president even though they had never before thought of it.

Next is about honesty. According to the three subjects, honesty is very much needed in running the wheels of the organization. All three subjects claimed to have tried to apply honesty in their time as well as possible. All things conveyed by the subject have also been justified by one of the Islamic Boarding School students of Jagad 'Alimussirry that the three subjects do have quite good social relations in their environment.

\section{- Leadership of BES JA}

First the researchers asked about the work program. The first subject answered that in the period there was a new work program, but there were still some obstacles. Whereas for the second and third subjects, there were no new work programs but developing work programs that had not been realized before, there were still some obstacles. The next question is about the enthusiasm of the JA community in participating in the BES work programs, the three subjects agreed to answer that the enthusiasm of the JA community was good enough although there were still some who had not heeded the BES work programs. The three subjects also claimed that one of the obstacles in carrying out work programs was the lack of good communication, both 
among BES management themselves, or between BES management and the JA community in general. In the third period of the subject, it was recognized that the JA community paid enough attention to what was conveyed by the President of BES, for example with the JA community carrying out the regulations that have been set and agreed upon by the President of BES with the ministers also with the approval of the director. Although there are still some who do not heed these regulations. but overall it's good enough.

In the opinion of one of the Jagad Islamic Boarding School students 'Alimussirry that in the period of President BES leadership was good enough. BES each period has advantages and disadvantages of each, as well as the President of BES which also has advantages and disadvantages of each. In his opinion, if the percentage of success of the BES President's leadership was made in all three periods, all of them exceeded $75 \%$, which means that it is good enough even though there are still some obstacles and shortcomings.

\section{- Relationship Between Spiritual Intelligence and The Success of President of BES JA's Leadership}

From the two previous discussions, it can be seen that the three subjects who are old president of BES JA have good spiritual intelligence. In addition, the three subjects can also be called successful in becoming president of BES JA in their respective periods even though their success rates have not yet reached perfection. Therefore, it can be said that good spiritual intelligence can influence the success of BES JA presidential leadership. And in general it can be said that spiritual intelligence is one of the factors that influence the success of a leader's leadership. This is in accordance with a statement by Hartono (2016) that the title of The Perfect Man actually reflects the perfect human figure who succeeded in carrying out his duties both as Abdullah (servant) and Caliph (leader) simultaneously. What is meant by The Perfect Man is a spiritualist who receives radiance from Allah SWT until he rises to reach a high level of dignity bearing the title of perfect man or become a holy guardian of God.

\section{CONCLUSSION}

From the explanation on the results and the previous discussion, it can be concluded that the level of spiritual intelligence of President BES, both the relationship to God and the relationship between beings, is good enough. In addition, during the period of the presidency of the BES President was also considered good with a percentage success rate of more than $75 \%$. From the two results along with the explanation of the explanation in the previous discussion, it can be seen that spiritual intelligence is one of the things that influences the success of the leadership of BES JA President. If a BES President has good spiritual intelligence, then the level of success of President BES JA's leadership is also high. So, the better the spiritual intelligence of President BES, the higher the success rate of BES President's leadership. The data that has been mentioned was obtained from interviews with research subjects who are old President of BES JA and also strengthened by data derived from interviews with one of the students of the Islamic Boarding School Jagad 'Alimussirry.

\section{ACKNOWLEDGMENT}

Praise the presence of Allah SWT who has given His grace and gifts to researchers, so that researchers can complete an article entitled "Implementation of Spiritual Intelligence in the Success of the Leadership of BES JA's President" smoothly. In completing this research, we did not escape obstacles and difficulties. However, thanks to the help and support of all parties related to us. Alhamdulillah, this article can be completed. Therefore, we thank: 
1. Dr. KH. Djoko Hartono, S.Ag., M.Ag., M.M as the caretaker of the Islamic Boarding School Jagad 'Alimussirry who has provided motivation in the field of religion and daily life.

2. M. Nurul Huda M.Pd. and Himmatul Aliyah, M.Pd. as a supervisor who has taken the time to guide and provide direction to researchers.

3. M. Nasih Aly, Mus'idah, Wardatul Marhamah, Izzatul Athiyah, Nur Maziyyatul Arofah, and Anjani Faiqotul Ulya as parents and beloved siblings of researchers who have provided motivation, prayers, and affection that always accompanies researchers .

4. The Sakno Chat Wong Telu team who have provided enthusiasm, motivation and entertainment during the process of completing a thesis to researchers

5. President of BES JA Demisioner who have taken the time to help researchers obtain data.

6. Sanih Gholiyah, Risma Ananda Putri, Nuril Fathurin, Rohmatul Hasanah, Resty Rahmatika, Linawati Arilia, and Hanida Kurnia Putri who have provided motivation and enthusiasm, also always reminded to immediately complete this proposal.

7. Friends of 2016 Islamic Boarding School JA and Mathematics Education who always inspire and provide support to researchers

8. All parties who have helped and supported researchers in completing this article that cannot be mentioned one by one.

Researchers realize that this article is far from perfect, therefore critics and suggestions are needed from all constructive parties. Do not forget the hopes of researchers that this article can be useful for readers and can increase reader knowledge.

\section{REFFERENCES}

Azis, Abdul.2017.Kepemimpinan Kiyai Sebagai Pemimpin Pendidikan di Pondok Pesantren Nurul Huda Pekandangan Barat Sumenep.Journal of Islamic Education Management. Vol.3.

Haris, Abdul.2017.Kepemimpinan (Leaership) dalam Pondok Pesantren, Madrasah, dan Sekolah.Al-Munawwaroh.Vol.9.

Hartono, Djoko.2011.Leadership :

Kekuatan Spiritualis Para

Pemimpin Sukses Dari Dogma

Teologis Hingga Pembuktian

Empiris. Surabaya : MQA Surabaya.

Hartono, Djoko.2016.Leadership :

Kekuatan Spiritualis Para

Pemimpin Sukses Dari Dogma

Teologis Hingga Pembuktian

Empiris. Surabaya : Ponpes Jagad Alimussirry.

Nurdin.Pengaruh Kepemimpinan dan

Kecerdasan Sosial Terhadap

Kinerja Karyawan.LP3I Jakarta.

Salutondok, Yohanis, Soegoto, Agus S.2015.Pengaruh

Kepemimpinan, Motivasi,

Kondisi Kerja, dan Disiplin Terhadap Kinerja Pegawai di Kantor Sekretariat DPRD Kota Sorong.Emba.Vol.3. 